\title{
THE ART OF MAVERICK POETRY
}

\section{Romulo P. Baquiran Jr.}

\section{About the Author}

Romulo P. Baquiran, Jr. teaches literature and creative writing courses at the College of Arts and Letters of the University of the Philippines in Diliman. He has published three poetry collections - Mga Tula ng Paglusong (1992), Onyx (2003), and Kung Nanaisin (2012)_ and two essay collections, Sagad sa Buto (2010) and Hiwatig: Pagsipat sa Tekstong Poetiko at Popular (2014). 
In his introduction to Histories, Charlie Samuya Veric says he shunned the barkada system of Manila's literati. Early on, he decided to be unattached; it took him a decade to present readers this collection. He confesses he created his poems the way a solitary monk would: avoid the literary coteries, Palanca contests, and the national writing workshops. Beginning Filipino writers are expected to collect these badge-like affairs to get noticed by the seniors, and by the readers as well. Veric believed in another: one's own.

Veric seems to have pulled this off in his first book of poems. He believes there are readers out there capacious enough to appreciate new poems sans benediction from prior lords. True to his free spirit, there is no mentor to praise his debut work. What readers would see in the first third of the book is his manifesto and poetics that sound very much like personal history and confident poetry. It is about the search for a conqueror's heart. Of course, this is all emblematic. But also very real for the writer.

His statements would sure earn smirks and admiration in equal measure from concerned parties, as he describes the pervasive literary cloning in academia among his seniors, and even contemporaries. Thus the need to escape what he calls "creative prison." The poet must achieve "expressive autonomy," says he.

Now, how do Veric's poems weigh against his expressed intentions and definitions? Well, the more than thirty poems are worthy of his artistic plan. He wrote them presumably when he was at Yale, and these show how much he has experienced life and honed his craft. There is evident beauty and apparent sadness that pervade his pieces which, by the way they sound, are really wise lyrics, some personal, and most take the disinterested point of view. The metrics give an elegant cerebral mood of nuanced feelings and affective sensitivity clothed in colloquial diction, incendiary rhetorical questions, and surprisingly smooth syntax. Most are relatively short, no more than a page or two, but are packed with subtle ironies and insights. Of course, if the reader wants to catch these charms, he has to misread the poems (said in the prologue "How To Read A Poem") beautifully.

One photo section marker points to one of the collection's main subjects: the inexorable past. It is a back view mirror, a metonym for the fatal look that predicates the persona's. The Benjamian angel is ever present in the eyes of the driver/writer. He cannot help but gaze into that real or imaginary portal. Thus, the poems.

A reader can imagine the presence of the mirror in these scenes from "Parting Time": "I imagine all the cabs on the boulevards of the world,/each different from the other, the passengers no more/different than us, all having one sorrow or another,/everybody hurtling away from paradise." 
Like a playlist, the insinuations of sadness and hope can be felt in the poetic threads. As in "If One of Those Fall Mornings," the persona as symbolized in the line "a carved pumpkin withering at the foot of a tree" is a bodhisattva in exile, albeit an alienated one but able to snap out of the ennui through nostalgia, recollecting a woman's picture and the sea, so at the end of the poem, he engages life once more, "Stood up, picked up my bag, started to walk into the day." Such feelings are more effusive in pieces like "Open Anew, My Heart" and "The Whole Truth." These poems from the second section stand in contrast to some pieces from the first section that features the more passionate lovers.

In "Sister Clytemnestra," the speaker addresses the Greek character and identifies with her all the more since their men have not changed through time. Murdering them is a transhistoric release of sweet justice. The pith of the apostrophe goes "...how alike they are: your man, my men: how blindly/they misjudge our flair for vengeance." The finale says: "When you struck that dagger/deep in Agamemnon's heart, ten long years after the war,/it was, first and foremost, because of love."

One of the most vivid poems in Histories is "Song." Singularly, it portrays the book's heartland. It flows and grips. The persona speaks to his village and family, its topography and history. One stanza mentions a brother who is an OFW in the Arabian desert. By association, he speaks to nation and the globalization of identities, the subject position of a Filipino. The images are not anything new or outlandish yet their accretion and order make true the promise made in the introduction. The topic is vernacular, i.e., common or familiar, although the style is not. It does not fall into the fine writing trap and the sonic grace is maintained to the end, which delivers a coup de grace of a line:

"Teach me to live the way a peak regards the sunset."

A poet and a maverick in the person of Charlie Samuya Veric is here for the capacious readers to discover. 